Native Apostles 



\section{NATIVE APOSTLES}

Black and Indian Missionaries in the

British Atlantic World

EDWARD E. ANDREWS

Harvard University Press

Cambridge, Massachusetts, and London, England 2013 
Copyright (C) 2013 by the President and Fellows of Harvard College

All rights reserved

Printed in the United States of America

Library of Congress Cataloging-in-Publication Data

Andrews, Edward E., 1979-

Native apostles : Black and Indian missionaries in the British Atlantic world / Edward E. Andrews.

p. cm.

Includes bibliographical references (p. ) and index.

ISBN 978-0-674-07246-6

1. Missions-History. 2. Indigenous peoples. 3.Missionaries. 4. African

American missionaries. 5. British-Atlantic Ocean Region-History. 6. United

States-History-Colonial period, ca. 1600-1775. 7. Great Britain-ColoniesAmerica-History. I. Title.

BV2120.A53 2013

266.0089'960171241-dc23 2012034736 
For Mary 
